\title{
PENGARUH SELF-ESTEEM DAN DUKUNGAN SOSIAL TERHADAP OPTIMISME MASA DEPAN ANAK JALANAN DI RUMAH SINGGAH JAKARTA SELATAN
}

\author{
Endang Multasih \\ UIN Syarif Hidaatullah \\ multasihendang@yahoo.co.id
}

\author{
Bambang Suryadi \\ Asosiasi Psikologi Islam \\ bangs1970@gmail.com
}

\begin{abstract}
The purpose of this study is to examine the effect of self-esteem and social support toward the optimism for future life of street children's at shelter (Rumah Singgah) South Jakarta. This study is also aimed at identifying the contribution of self-esteem and social support toward the optimism for future life of street children. This study applied quantitative method using multiple regression for data analysis. The population of this study is 400 street children and the sample size is 250 street children. The sample size consisted of $173(69,2 \%)$ males and 77 $(30,8 \%)$ females, aged form 12 to 18 years. The sample of this study was selected using non probability sampling technique. In collecting the data, this study used three instruments. They are optimism for future life, self-esteem, and social support in the form of Likert scale model. The findings of the study indicate that there is significant effect of self-esteem and social support toward the optimism for future life of street children with the significance value at $0,000(p>0,05)$. The $R$-square $\left(R^{2}\right)$ value is 0,286 which means that about $28,6 \%$ of the optimism for future life of street children is determined by the self-esteem and social support.
\end{abstract}

Keywords: Optimism for future life,self-esteem, social support, and street children.

\begin{abstract}
Abstrak
Tujuan dari penelitian ini untuk menguji pengaruh dari self-esteem dan dukungan sosial terhadap optimisme masa depan anak jalanan yang tinggal di penampungan (Rumah Singgah) Jakarta Selatan. Peelitian juga bertujuan untuk menguji kontribusi dari selfesteem dan dukungan sosial terhadap optimisme masa depan anak jalanan. Penelitian ini menggunakan metode kualitatif dengan regresi berganda untuk analisis data. Populasi dari penelitian ini adalah 400 anak jalanan dan sampel adalah 250 anak jalanan. Sampel terdiri dari 173 (69,2\%) laki-laki dan 77 (30,8\%) perempuan, usia 12-18 tahun. Sampel dipilih dengan teknik sampel non probability. Untuk pengumpulan data menggunakan tiga instrumen, yaitu skala optimisme masa depna, skala self-esteem, dan skala dukungan sosial dalam bentuk Likert. Hasil penelitian menunjukkan pengaruh yang signifikan dari selfesteem dan dukungan sosial terhadap optimisme amasa depan anak jalanan dengan nilai signifikansi 0,000 ( $p>0,05)$. Nilai R-square $\left(R^{2}\right)$ 0,286 atau 28,6\% optimisme masa depan anak jalanan dipengaruhi oleh self-esteem dan dukungan sosial.
\end{abstract}

Kata Kunci: Optimisme Masa Depan, Self-Esteem, Dukungan Sosial, Anak Jalanan. 


\section{PENDAHULUAN}

Keberadaan anak jalanan memang sudah lazim muncul di kota-kota besar di Indonesia. Jumlah anak jalanan mengalami peningkatan pesat dalam beberapa tahun belakangan. Riyanti (2010) mengemukakan berdasarkan Pusat Data dan Informasi Kementrian Sosial 2008 diperkirakan jumlah anak jalanan di Indonesia pada tahun 2006 sebanyak 144.000 jiwa, kemudian menjadi 104.000 jiwa pada tahun 2007 dan meningkat menjadi 232.984 jiwa pada tahun 2008. Fenomena anak jalanan terlihat nyata di kota-kota besar seperti Jakarta. Afifah (2011) menjelaskan berdasarkan data dari Dinas Sosial DKI Jakarta, jumlah anak jalanan pada tahun 2009 sebanyak 3.724 jiwa lalu meningkta menjadi 5.650 jiwa pada tahun 2010 dan 7.135 jiwa tahun 2011, kemudian pada tahun 2012 sekitar 8.000 jiwa (More, 2012). Kementrian Sosial (2009) mendefinisikan anakjalanan sebagai anak yang berusia 5-18 tahun yang menghabiskan sebagian besar waktunya untuk mencari nafkah dan berkeliaran di jalan maupun di tempat umum.menurut Sudrajat dalam Kuntjorowati (2011), terdapat tiga kategori anak jalanan: (1) Children of Street yaitu anak yang hidup di jalanan, putus hubungan dengan keluarga, tidak sekolah dan tinggal di jalanan; (2) Children on the Street yaitu anak yang bekerjadi jalanan, tidak sekolah, berhubungan tidak teratur dengan keluarganya; dan (3) Vulnerable to be Street yaitu anak yang rentan menjadi anak jalanan, masih sekolah maupun putus sekolah, dan masih berhubungan secara teratur dengan orang tuanya. Dari tiga kategori tersebut, yang menjadi fokus penelitian ini adalah jenis vulnerable to be street.

Terdapat beberapa hal yang menyebabkan terjadinya fenomena anak jalanan. Rochatun dan Sigalingging (2012) menemukan tiga hal yang melatar belakangi terjadinya eksploitasi anak yaitu kemiskinan, pengaruh lingkungan serta keretakan rumah tangga orang tua. Keterbatasan ekonomi menjadi hal yang sangat dominan bagi turunnya anak ke jalan. Hal ini didukung oleh Tjahjorini, Slamet, Asngari, dan Susanto (2005) yang menemukan bahwa 93,33\% dari anak jalanan mengaku berasal dari keluarga tidak mampu. Dampak dan akibat lebih lanjut dari kondisi tersebut yaitu semakin banyaknya anak yang harus meninggalka sekolah guna mencri nafkah di jalan (Tjahjorini dkk, 2005). Hal ini senada dengan Hosein (2003) yang menyebutkan bahwa anak jalanan hampir tidak memiliki akses terhadap pelayanan pendidikan, kesehatan dan perlindungan. Di tengah 
kondisi tersebut, anak jalanan diharapkan memiliki sikap yang baik akan masa depannya yang disebut optimisme.

Salah satu masalah yang dihadapi anak jalanan adalah optimism masa depan. Menurut Weinstein (1980) optimisme masa depan berkaitan dengan masalah pendidikan, pekerjaan, perkawinan, kesehatan, dan sebagainya. Terdapat beberapa aspek dalam optimisme diantaranya adalah (1) Permanent yaitu gaya penjelasan yang berkaitan dengan waktu yang dibedakan menjadi temporer dan permanen. Individu optimis percaya bahwa peristiwa buruk bersifat temporer dan peristiwa baik bersifat permanen, begitupun sebaliknya pada individu pesimis; (2) Pervasive yaitu gaya penjelasan yang berkaitan dengan dimensi ruang lingkup yang dibedakan menjadi spesifik dan universal. Individu optimis percaya bahwa peristiwa buruk bersifat spesifik, sedangkan peristiwa baik bersifat universal, begitupun sebaliknya pada individu pesimis; (3) Personalization yaitu gaya penjelasan yang berkaitan dengan sumber penyebab yang dibedakan menjadi internal dan eksternal. Individu optimis mempercayai peristiwa baik secara internal yaitu diri sendiri yang menjadi penyebabnya dan mempercayai peristiwa buruk secara ekternal yaitu orang lain atau lingkungan yang menjadi penyebabnya, begitupun sebalikny pada individu pesimis.

Namun kenyataannya, kurangnya optimisme masa depan merupakan masalah yang muncul dari anak jalanan. Survei yang dilakukan peneliti pada salah satu Rumah Singgahh menemukan beberapa hal yang membuat anak jalanan tidak optimis dalam memandang masa depan di antaranya ekonomi (75\%), rasa takut tidak tercapainya cita-cita $(62,5 \%)$, kurangnya dukungan dari orang tua $(37,5 \%)$, pergaulan teman $(12,5 \%)$, rasa takut masa depannya sama seperti orang di sekitarnya $(12,5 \%)$ dan pikiran negatif bahwa ia tidak akan berhasil (12,5\%).

Terdapat banyak faktor yang mempengaruhi optimisme masa depan, salah satunya faktor internal yaitu self-esteem. Self-esteem adalah penilaian terhadap diri sendiri, tolak ukur harga diri kita sebagai manusia, berdasarkan pada kemampuan penerimaan diri dan perilaku sendiri (Minchinton, 1993). Sedangkan menurut Devito (2006) self-esteem merupakan evaluasi seseorang terhadap apa yang ia rasakan terhadap dirinya, bagaimana ia menyukai dirinya dan seberapa kompeten ia dapat menilai dirinya sendiri. Self-esteem terdiri dri tiga aspek di antaranya adalah (1) Perasaan mengenai diri sendiri yaitu menerima dan memaafkan kesalahan diri, menghargai nilai pribadi dan mampu mengendalikan emosi 
diri; (2) Perasaan terhadap hidup yaitu menerima kenyataan dengan tidak menyalahkan hidup atas masalah yang dihadapi dan memegang kendali atas diri sendiri; dan (3) hubungan dengan orang lain yaitu toleran dan menghargai orang lain dan bijaksana dalam menjalin hubungan (Michinton, 1993).

Beberapa penelitian menunjukkan bahwa self-esteem berhubungan dengan optimisime pada penelitian Sandoval (2008) mengenai secure attachment, self-esteem, dan optimisme sebagai prediktor citra tubuh positif ditemukan bahwa optimisme dan self-esteem berkorelasi positif. Selain itu, penelitian Puskar, Ren, Bernado, Halely, dan Stark (2009) menemukan bahwa self-esteem dan optimisme berkorelasi negatif dengan pengendalian amarah.

Selain self-esteem, dukungan sosial merupakan faktor eksternal yang mampu mempengaruhi optimisme seseorang. Dukungan sosial meliputi kenyamanan yang dirasakan, perhatian, penghargaan atau bantuan yang diperoleh individu dari orang lain maupun kelompok (Sarafino, 1998). Sedangkan menurut House dan Kahn dalam Thoits (1995) dukungan sosial biasanya mengacu pada fungsi yang dilakukan orang yang signifikan seperti keluarga, teman, dan rekan kerja yang memberikan bantuan instrumental, informasi, penilaian dan emosional. Dukungan sosial terdiri dari lima aspek di antaranya (1) Dukungan emosional meliputi sikap empati, peduli dan perhatian; (2) Dukungan penghargaan meliputi penilaian postif, dorongan maju dan semangat; (3) Dukungan instrumental meliputi bantuan barang dan jasa; (4) Dukungan informasi meliputi nasehat, arahan, saran, tanggapan dan cara yang digunakan untuk memecahan masalah; dan (5) Dukungan jaringan meliputi interaksi sosial positf dimana individu dapat merasa bahwa dirinya bagian dari kelompok dan dapat menghabiskan waktu dalam suatu aktivitas sosial.

Dukungan sosial memiliki pengaruh positif yang dapat mengurangi gangguan psikologis akibat tekanan (Rustiana, 2006). Boland dan Cappeliezdalam Shelby, Crespin, dan Sharla (2008) mengindikasikan bahwa dukungan sosial secara positif berkorelasi dengan optimisme. Ekas, Lickencrock dan Whitman (2010) menemukan bahwa dukungan keluarga berhubungan dengan meningkatnya optimisme yang akan memprediksi kesejahteraan Ibu.

Pada kota-kota besar di Indonesia, pemerintah membentuk Lembaga Swadaya Masyarakat (LSM) seperti Rumah Singgah sebagai alternatif penanganan anak jalanan. Rumah Singgah memiliki fungsi sebagai tempat 
pertemuan anak denan keluarga, pekerja sosial dan lembaga, pusat rujukan, tempat perlindungan, informasi, kuratif dan rehabilitatif, akses terhadap pelayanan serta resosialisasi (Effensy, Frieda, dan Warsono, 2008). Berdasarkan observasi peneliti pada Rumah Singgah di Jakarta Selatan, terdapat beberapa dukungan yang didapatkan anak jalanan yaitu kepedulian dan perhatian, penilaian positif dan dorongan semangat, bantuan materi yang dibanttu oleh Dinas Sosial DKI Jakarta dan Kementrian Sosial RI serta bantuan jasa, nasehat serta interaksi sosial di berbagai aktivitas sosial.

Berdasarkan latar belakang masalah yang telah diuraikan di atas, rumusan masalah penelitian ini adalah sebagai berikut:

1. Apakah ada pengaruh yang signifikan dari self-esteem dan dukungan sosial terhadap optimisme masa depan anak jalanan di Rumah Singgah Jakarta Selatan.

2. Apakah ada pengaruh yang signifikan dari masing-masing aspek selfesteem (perasaan mengenai diri sendiri, perasaan terhadap hidup dan hubungan dengan orang lain) dan aspek dukungan sosial (dukungan emosional, dukungan penghargaan, dukungan instrumental, dukungan informasi, dan dukungan jaringan) terhadap optimisme masa depan anak jalanan di Rumah Singgah Jakarta Selatan.

3. Berapa besar kontribusi variabel self-esteem dan dukungan sosial terhadap optimisme masa depan anak jalanan di Rumah Singgah Jakarta Selatan.

Penelitian ini bertujuan untuk mengetahui pengaruh self-esteem dan dukungan sosial terhadap optimisme masa depan anak jalanan di Rumah Singgah Jakarta Selatan serta kontribusi yang diberikan oleh self-esteem dan dukungan sosial terhadap optimisme masa depan.

Manfaat teoritis dari hasil penelitian ini adalah untuk menambah wacana keilmuwan bagi disiplin ilmu psikologi khususnya psikologi positif mengenai optimisme masa depan, self-esteem dan dukungan sosial. Sedangkan manfaat praktis dari hasil penelitian ini adalah untuk memberikan informasi kepada orang tua, pihak Rumah Singgah dan masyrakata mengenai optimisme masa depan dan selfesteem anak jalanan serta dukungan yang dibutuhkan oleh mereka.

\section{METODE}

Penelitian ini menggunakan pendekatan kuantitatif dengan analisis regresi berganda. Populasi dari penelitian ini adalah anak jalanan dengan rentang usia 12-18 tahun, merupakan kategori Vulnarable to be Street dan berada di 
Rumah Singgah Jakarta Selatan yang berjumlah 400 anak. Dari jumlah tersebut peneliti memilih 250 anak sebagai sampel penelitian. Sampel tersebut terdiri atas $17(69,2 \%)$ laki-laki dan 77 (30,8\%) perempuan. Teknik pengambilan sampel dalam penelitian ini menggunakan teknik non probability sampling.

Instrumen penelitian yang digunakan untuk pengumpulan data adalah skala optimisme masa depan, skala self-esteem dan skala dukungan sosial dengan model skala Likert. Uji validitas pada penelitian ini menggunakan confirmatory factor analysis (CFA). Teknik analisis data yang digunakan adalah teknik regresi berganda (multiple regression).

\section{HASIL}

Hasil penelitian menunjukkan terdapat pengaruh yang signifikan variabel self-esteem dan dukungan sosial terhadap optimisme masa depan anak jalanan di Rumah Singgah Jakarta Selatan dengan nilai signifikansi 0,000 (p $>0,05)$. Nilai koefisien $R$-square $\left(\mathrm{R}^{2}\right)$ sebesar 0,286 yang menunjukkan bahwa $28,6 \%$ proporsi varian optimisme masa depan dalam penelitin ini diberikan oleh variabel self-esteem dan dukungan sosial.

Koefisien regresi masing-masing dimens variabel independen dapat dilihat dalam tabel berikut ini

Tabel 1

Koefisien Regresi Variabel Indepen

\begin{tabular}{lcc}
\hline \multicolumn{1}{c}{ Variabel } & Koefisien & Regresi \\
\hline Self-esteem & & \\
1. Perasaan mengenai diri sendiri & 0.138 & (Sig) \\
2. Perasaan terhadap hidup & 0.244 & (Sig) \\
3. Hubungan dengan orang lain & 0.070 & (Non-sig) \\
Dukungan sosial & & \\
1. D. Emosional & -0.044 & (Non-sig) \\
2. D. Penghargaan & 0.310 & (Sig) \\
3. D. Intrumental & -0.013 & (Non-sig) \\
4. D. Informasi & 0.041 & (Non-sig) \\
5. D. Jaringan & 0.020 & (Non-sig) \\
\hline
\end{tabular}

$$
\mathrm{D}=\text { Dukungan }
$$

Data pada Tabel 1 di atas menunjukkan bahwa ada tiga dimensi yang berpengaruh signifikasni terhadap optimisme masa depan yaitu perasaan 
mengenai diri sendiri $(p=0,26<0,05)$, perasaan terhadap hidup $(p=0,000$ $<0,05)$ dan dukungan enghargaan $(p=0,000<0,05)$. Sedangkan hubungan dengan orang lain, dukungan emosional, dukungan instrumental, dukungan informasi dan dukungan jaringan tidak memiliki pengaruh yang signifikan terhadap optimisme masa depan.

Analisis terhadap proporsi varian $\left(\mathrm{R}^{2}\right)$ menunjukkan bahwa perasaan mengenai diri sendiri memberikan kontribusi sebesar 9,6\%, perasaan terhadap hidup memberikan kontribusi sebesar $9,3 \%$ dan dukungan penghargaan memberikan kontribusi sebesar 7,6\% terhadap optimisme masa depan.

Berdasarkan hasil penelitian terbukti bahwa terdapat pengaruh yang signifikan antara self-esteem dan dukungan sosial terhadap optimisme masa depan anak jalanan di Rumah Singgah Jakarta Selatan. Dalam penelitian ini, self-esteem dan dukungan sosial memberikan kontribusi sebesar 28,6\% terhadap optimisme masa depan. Hal tersebut menunjukkan bahwa semakin tinggi selfesteem anak jalanan dan dukungan sosial yang didapatkan, maka semakin tinggi optimisme masa depan anak jalanan.

Hal ini sesuai dengan hasil penelitian sebelumnya, Symister dalam Sumer (2009) mengindikasikan bahwa dukungan sosial beroperasi dengan self-esteem dalam mempengaruhi optimisme dan depresi pada individu penderita penyakit kronis. Menurut Vinacle dalam Nurtjahjanti \& Ratnaningsih (2011), self-esteem merupakan faktor yang dapat mempengaruhi optimisme. Hasil penelitian ini juga sealan dengan Puskar., dkk (2010) yang menemukan korelasi positif antara self-esteem dan optimisme pada remaja pedesaan.

Selain itu, penelitian inijuga mendukung penelitian Friedman, Kane, dan Cornfield (1998) yang menemukan bahwa manajer kulit hitam yang memiliki kelompok jaringan di perusahaannya akan lebih optimis mengenai karir mereka dibandingkan yang tidak memiliki kelompok jaringan. Hal ini sejalan dengan penelitian Shelby (2008) yang menemukan bahwa penerimaan dukungan sosial merupakan sumber penting untuk seseorang dengan tingkat optimisme yang rendah.

Namun jika variabel self-esteem dan dukungan sosial dijabarkan satu per satu berdasarkan koefisien regresi, maka hanya akan ditemukan tiga variabel dari self-esteem dan dukungan sosial yaitu perasaan mengenai diri sendiri dan perasaan terhadap hidup serta dukungan penghargaan yang memberikan pengaruh signifikan terhadap optimisme. 
Perasaan mengenai diri sendiri memberikan kontribusi sebesar 9,6\%. Artinya semakin anak jalanan mampu menerima dirinya serta memaafkan kesalahan dirinya maka semkain anak jalnan mampu bersikap optimis dalam memandang masa depan. Pada kenyataannya, mereka kecewa akan keadaannya dan menunjukkan bahwa terdapat perbedaan antara gambaran tentang siapa dirinya dnegan gambaran seseorang tentang seharusnya ia menjadi (Pardede, 2008). Hal ini menunjukkan bahwa harga diri akan mempengaruhi optimisme masa depan mereka.

Variabel perasaan terhadap hidup dalam penelitian ini memberikan kontirbusi sebesar 9,3\%. Menurut Effendy (2008), anak jalanan kehilangan hak dan ditelantarkan oleh keluarganya karena kemiskinan sehingga mendorong mereka untuk mencari nafkah di jalan yang seharusnya belum menjadi tanggung jawab mereka. mereka berada pada kondisi yang kurang beruntung dan berbeda denga anak-anak pada umumnya sehingga mereka memiliki perasaan terhadap hidup yang mampu mempengaruhi sikap optimis mereka.

Kemudian dukungan penghargaan memberikan kontribusi sebesar 7,6\%.menurut Karademas (2006) dalam rangka mempertahankan optimisme, seseorang mengandalkan kemampuan pribadi serta penilaian positif dari lingkungan sosial. Hal ini juga senada dnegan Skinner dalam Tjahjorini (2006) yang menunjuk penghargaan sosial sebagai faktor yang membentuk sikap dan perilaku. Oleh karen aitu, ketika anak jalanan merasa dihargai, dinilai positif serta diberikan semangat oleh orang di sekitarnya khususnya dalam penelitian ini pihak Rumah Singgah, maka mereka akan lebih optimis dalam memandang masa depan.

Sementara variabel lain yaitu hubungan dengan orang lain, dukungan emosional, instrumental, informasi dan jaringan sosial tidak memberikan pengaruh yang signifkan terhadap optimisme masa depan. Dengan kata lain optimisme masa depan yang tinggi tidak hanya membtutuhkan hubungan dengan orang lain, dukungan emosional, instrumental, informasi dan jaringan yang tinggi.

Berkaitan dengan tidak ditemukannya pengaruh yang signifikan dari variabel self-esteem terhadap optimisme masa depan, kemungkinan dipengaruhi oleh pandangan negatif anak jalanan terhadpa orang lain. Berdasrkan observasi peneliti terhadap anak jalanan di Yayasan Nanda Dan Nusantara, sebesar $12,5 \%$ dari mereka menyatakan bahwa rasa takut akan masa depanya sama seperti orang-orang di sekitarnya dapat membuat mereka tidak optimis dalam memandang masa depan. Selain itu peneliti 
berasusmsi bahwa seseorang akan cenderung mendahulukan perasaan mereka sendiri, baik terhadap diri sendiri maupun hidupnya dibandingkan dengan hubungannya dengan orang lain.

Selain itu, mengenai tidak ditemukannya pengaruh yang signifikan dari empat variabel dukungan sosial kemungkinan dipengaruhi oleh perbedaan subjek penelitian sehingga terdapat pula perbedaan dukungandukunggan yang dibutuhkan dan perbedaan pengalaman masa lalu. Scheier dalam Synder (2002) menyatakan bahwa pengalaman masa lalu berkaitan dengan bagaimana seseorang memiliki kepercayaan dasar. Menurut asumsi peneliti, pengalaman masa lalu dapat menyebabkan prasangka ketia mendapatkan sebuah dukungan dari orang di sekitarnya.

\section{DISKUSI}

Hasil penilitian dapat disimpulkan sebagai berikut:

1. Terdapat pengaruh yang siginifikan variabel self-esteem dan dukungan sosial terhadap optimisme masa depan anak jalan di Rumah Singgah ( $p$ $=0,000<0,05$ dan $\mathrm{R} 2=28,6 \%$ ).

2. Dari tiga dimensi self-esteem terdapat dua dimensi yang memeiliki pengaruh siginfikan terhadap optimisme masa depan, yaitu perasaan mengenai diri sendiri $(\mathrm{p}=0,026<0,05)$ dan perasaan terhadap hisup ( $\mathrm{p}$ $=0,00<0,05)$. Sedangkan dari lima dimensi dukungan sosial terdapat satu dimensi yang memiliki pengaruh signifikan, yaitu dukungan penghargaan $(p=0,000<0,05)$.

3. Jika dilihat berdasarkan proporsi varians, perasaan mengenai diri sendiri memberikan kontrubis sebesar 9,6\%, perasaan terhadap hidup memberikan kontribusi sebesar 9,3\% dan dukungan penghargaan yang memberikan kontribusi sebesar 7,6\% terhdapa optimisme asa depan anak jalanan di Rumah Singgah Jakarta Selatan.

\section{DAFTAR PUSTAKA}

Afifah, Riana. 2011. Jumlah anak jalanan meningkat signifikan. Diakses tanggal 21 Juli 2012 pukul 10.25 wib dari Kompas.com. (http://megapolitan.kompas.com/read/2011/08/24/1641249/Jumla h.Anak.Jalanan.Meningkat.Singnifikan)

Devito, J.A. ( 2006). Human communication: The basic courge (10th edition). USA: Pearson Education, Inc. 
Effendy, Muhammad., Frieda., \& Warsono, Hardi. (2008). Evaluasi penanganan anak jalanan pada Rumah Singgah di kota Semarang. Jurnal Ilmu Administrasi dan Kebijakan Publik, Vol. 5, No.1, 137-154.

Ekas, N., Lickenbrock, D. M., \& Whitman, T. L. (2010). Optimism, social support and well-being in mothers of children with Austism Spectrum Disorder. Journal of Autism Dev Disord, Vol. 40, 1274-1284.

Friedman, R., Kane., M., \& Cornfield, D. (1998). Social support and career optimism: Examining the effectiveness of network groups among black managers. Journal of Human Relations, Vol. 51, No. 9. 1155-1177.

Ghufron \& Risnawita. 2010. Teori-teori psikologi. Jogjakarta: Ar ruzz media.

Hoesin, Iskandar. 2003. Perlindungan terhadap kelompok rentan (wanita, anak, minoritas, suku terasing, dll) dalam perspektif hak asasi manusia. Makalah seminar pembangunan hukum nasional ke VIII. Disajikan pada tanggal 14-18 Juli. Bali.

Karademas, Evangelos. (2006). Self-efficacy, social support and well being: The mediating role of optimism. Journal of Personality and Individual Differences, Vol. 40, 1281-1290.

Kuntjorowati, Elly. (2011). Pemberdayaan anak jalanan: Studi kasus pada Sanggar Alang-alang Surabaya dan Yayasan Peduli Anak Lombok Barat. Jurnal PKS, Vol. 10, No. 4, 378-393.

Minchinton, Jerry. (1993). Maximum self esteem : The handbook for reclaiming your sense of self worth. Kuala Lumpur: Golden Books Center Sdn, Bhd.

More, Imanuel. 2012. Pusat perbelanjaan bertambah, gelandangan meningkat. Diakses tanggal 21 Juli 2012 pukul 10.47 wib dari Kompas.com. (http://megapolitan.kompas.com/read/2012/05/12/19373939/Pusa t.Perbelanjaan.Bertambah.Gelandangan.Meningkat)

Nurtjahjanti, H., \& Ratnaningsih, I. (2011). Hubungan kepribadian hardiness dengan optimisme pada calon tenaga kerja Indonesia (CTKI) wanita di BLKLN Disnakertrans Jawa Tengah. Jurnal Psikologi Undip Vol. 10, No. 2, 126-132.

Pardede, Yudit. (2008). Konsep diri anak jalanan usia remaja. Jurnal Psikologi Vol. 1 No. 2.

Puskar, K., Ren, D., Bernado, L.M., Haley, T., \& Stark, K.H. (2009). Anger correlated with psychosocial variables in rural youth. Journal of Compr Pediatr Nurse, Vol. 31, No. 2, 71-87.

Puskar, K., Ren, D., Bernado, L.M., Haley, T., \& Stark, K.H., Switala., Siemon. (2010). Self esteem and optimism in rural youth: Gender differences. Journal of Contempory Nurse, Vol. 34, No. 2, 190-198.

Riyanti, Nova. 2010. Melirik kondisi kejiwaan anak jalanan. Diakses tanggal 21 Juli 2012 pukul 10.13 wib dari Seputar-indonesia.com. (http://www.seputar-indonesia.com/edisicetak/content/view/ $324718 /$ ) 
Rochatun, Isti., Suprayogi., \& Sigalingging, H. (2012). Eksploitasi anak jalanan sebagai pengemis di kawasan Simpang Lima Semarang. Journal of Unnes Civic Education, Vol.1, No.1. 22- 29.

Rustiana, Eunike. 2006. Dukungan sosial dan pengaruhnya bagi kesehatan. Jurnal Kesehatan Masyarakat, Vol. 1, No.2, 127-135.

Sandoval, E. L. (2008). Secure attachment, self esteem and optimism as a predictors of positive body image in women. Disertation of counseling psychology. Texas: Texas A\&M University.

Sarafino, Edward. P. (1998). Health psychology: Biopsychosocial interaction. New York: John Wiley \& Sons, Inc.

Shelby, R., Crespin, R., Sharla, M. (2008). Optimism, social support, and adjustment in African American women with breast cancer. Journal of Behavior Medicine, Vol. 31, 433-444.

Snyder, C.R., \& Lopez, S.J. (2002). Handbook of positive psychology. New York: Oxford Univestity Press.

Sumer, M., Giannotta, F., Settanni, M., \& Ciairano, S. (2009). Parental support as mediator between optimism and depression in early adolescents. Journal of Psychology and Counseling, Vol. 1, No. 18, 139146.

Tjahjorini, S., Slamet, M., Asngari, P., \& Susanto, D. (2005). Persepsi anak jalanan terhadap bimbingan sosial melalui Rumah Singgah di kotamadya Bandung. Jurnal Penyuluhan, Vol.1, No.1, 21-32.

Tjahjorini, S. (2006). Faktor-faktor yang mempengaruhi perilaku anak jalanan di Bandung, Bogor dan Jakarta. Laporan penelitian: Departemen Sosial.

Weinstein, Neil. D. (1980). Unrealistic optimism about future live events. Journal of Personality and Social Psychology. Vol. 39, No. 5, 806-820. 
